\section{SUMMARY}

This article outlines forthcoming changes to the National Accounts and Balance of Payments. The Office for National Statistics (ONS) aims to introduce data on derivatives business of UK banks into the financial accounts and balance sheets for the 2010 Blue Book and Balance of Payments Pink Book. Revisions will go back to the start of 2006.

In the National Accounts, currently only limited transaction data is published for the bank, central government and rest of the world sectors. Data for the rest of the world sector is also presented within the Balance of Payments statistics. Additional balance sheet data is published annually in Blue Book Table 4.5 and Pink Book Table FD.

Derivative transactions which take place exclusively between other sectors of the economy, such as other (non-bank) financial institutions and private nonfinancial corporations, will be included once reliable data sources are available.

\title{
Incorporating derivatives data in the National Accounts and Balance of Payments
}

\section{Background}

- he European System of Accounts (1995) defines derivatives as

financial assets based on or derived from a different underlying instrument. The underlying instrument is usually another financial asset, but may also be a commodity or an index. Financial derivatives are also referred to as secondary instruments and since the hedging or offsetting of risk is frequently a motivation for their creation, they can be referred to as hedging instruments. Only those secondary instruments, which have a market value, because they are tradable or can be offset on the market, are financial assets in the system of accounts and are classified as derivatives. Derivatives include:

- Options - both tradable and over-thecounter (OTC). These are contingent assets which give their holders the right, but not the obligation, to purchase from (in the case of a call option) or to sell to (in the case of a put option) the issuer of the option (the option writer) financial or non-financial assets (the underlying instrument) at a predetermined price (the strike price) within a given time span (American option) or on a given date (European option). The purchaser of the option pays a premium (the option price) for the commitment of the option writer to sell or to purchase the specified amount of the underlying asset or to provide, on demand of the purchaser, appropriate remuneration. By convention, that commitment is treated as a liability of the option writer because the option price represents the current cost to the option writer of buying out the contingent liability

- Warrants - these are a form of tradable options, which give their holders the right to purchase from the issuer of the warrant (usually a corporation) a certain number of shares or bonds under specified conditions for a designated period of time. There is also currency warrants, the value of which is based on the amount of one currency required to purchase another currency at or before the expiration date of the warrant and cross-currency warrants tied to third currencies. The issuer of the warrant is considered to have incurred a liability representing the current cost of buying out the contingent liability

- Futures - but only if they have a market value because they are tradable or can be offset. Futures are commitments to deliver, or to take delivery of, a specified quantity of a standard grade of a commodity, foreign exchange, or a security at a fixed price and for a specified delivery date or period. Futures may also be based on an index rather than a specific financial or nonfinancial asset

- Swaps - but only if they have a market value because they are tradable or can be offset. Swaps are contractual arrangements between two parties who agree to exchange, over time and 
according to predetermined rules, streams of payment of the same amount of indebtedness. The most prevalent varieties are interest rate swaps, foreign exchange swaps and currency swaps (also named cross-currency interest swaps). Interest rate swaps involve an exchange of interest payments of different character, such as fixed rate for floating rate, two different floating rates, fixed rate in one currency and floating rate in another, and so on. Foreign exchange swaps (including all forward contracts) are transactions in foreign currencies at a rate of exchange stated in advance. Currency swaps involve an exchange of specified amounts of two different currencies with subsequent repayments, which include both interest and repayment flows, over time according to predetermined rules

- Forward rate agreements (FRAs) - but only if they have a market value because they are tradable or can be offset. FRAs are contractual arrangements in which two parties; in order to protect themselves against interest rate changes, agree on an interest to be paid, at a settlement date, based on a notional amount of principal that is never exchanged. The payments are related to the difference between the agreement rate and the prevailing market rate at the time of settlement.

Derivatives do not include:

- the underlying instrument upon which the financial derivative is based

- repayable margin payments related to financial derivatives. They are classified in other deposits or loans depending on the institutional units involved

- secondary instruments, which are not tradable and cannot be offset on the market

Derivatives are widely used in the financial and commercial sectors, both for hedging against risk and also, in the case of financial institutions that specialise in the derivatives markets, market-making and trading in derivatives for profit. Derivatives have also been introduced indirectly to the fields of retail finance and savings - examples of where derivatives are linked to financial products might include fixed-rate or capped mortgages, or equity-linked investment bonds offering investors a return linked to rises in a stock index, while offering an element of protection against future falls in the value of the index.
Usage of derivatives have expanded beyond purchasing commodity contracts to ensure future supplies of a raw material at a pre-determined price. The growth in derivatives usage has been driven in part by the greater commercial (and regulatory) emphasis on risk management in the conduct of an enterprise's business. The main risk determinants are foreign exchange, interest-rate, and commodityrelated (including more recently power and gas). Derivatives markets are constantly innovating, and new risk variants or products continually appear.

Transactions will be shown on a net basis (assets less liabilities) for each sector, whereas positions will be shown on a gross (total assets and total liabilities) basis. Semken (2005) may provide readers with useful background information.

\section{Methodology}

Banks enter into derivative agreements with other banks, other financial corporations, non-financial corporations, government, householders and units overseas. When recording an asset/liability for the banking sector, the corresponding liability/asset sector is also identified. For example if a UK bank holds a derivative contract with a tradable positive value of $£ 1$ million which can be redeemed at an overseas bank, the asset sector is the UK banking sector and the liability sector is the rest of the world sector.

Balance sheet data for the banking sector is collected quarterly by the Bank of England in a specialised Derivatives survey (the DQ form). This survey contains a detailed analysis of reporting banks assets and liabilities by economic sector of counterparty.

In order to estimate transactions data the following model is used:

Change in value of derivatives portfolio $=$ Net transactions + Net holding gains/losses Re-arranging this equation shows:

Net transactions $=$ Change in value of derivatives portfolio - Net holding gains/ losses

Net holding gains/losses are approximated as:

Dealing profits - Net spread earnings

Therefore, by approximating net holding gains/losses as dealing profits less net spread earnings transactions data can be estimated by subtracting dealing profits less net spread earnings from the change in balance sheet data over the period.
The dealing profits and net spread earnings of UK banks are also collected by the Bank of England (via the Profit and Loss (PL) survey) and provide aggregate data for the banking sector.

The PL form provides counterpartied information for dealing profits and net spread earnings, separated out between the UK and overseas sectors. However there is no information on counterparties within the UK sector. As an approximation, the sector positions (of the previous quarter) from the balance sheets have therefore been used to apportion the transaction data amongst the domestic sectors.

The sector detail on banks' aggregate positions from the DQ survey, although identifying banks and building societies as separate sub-groups of counterparty, is restricted to 'other financial corporations' for the residual category within the financial sector. In order to create balance sheet data for the two sub-sectors of the other financial corporations sector (that is the insurance and pension funds (IP) sector and the other financial institutions (OI) sector), proxy information on the level of banks' deposit liabilities (OI and IP assets) and banks' short-term lending (OI and IP liabilities) for the same end-period is used. For transactions in the financial account, the same proxy ratios are used, but lagged by one quarter.

For more information on this method for deriving transactions data, please see the Annex to this article.

The balance sheet data are consistent with Table F1.1 of the Bank of England's publication Monetary and Financial Statistics (see Bank of England 2010).

The transaction and balance sheet data for all sectors will be published in the United Kingdom Economic Accounts (see ONS 2010), and downloadable from the ONS website, from the 30 June 2010. Balance of Payments balance sheet data will be reported in Table 8.1 and a geographic breakdown of the balance sheet will be recorded in Table 10.1.

\section{Impact}

Incorporating bank sector derivatives data into the National Accounts will result in significant revisions to balance sheets. Figure 1 shows total assets and liabilities for the banking sector. Please note, the overall net worth of the banking sector remains largely unaffected as revisions to gross assets are offset by revisions to gross liabilities. For an indication of the effects on the balance 


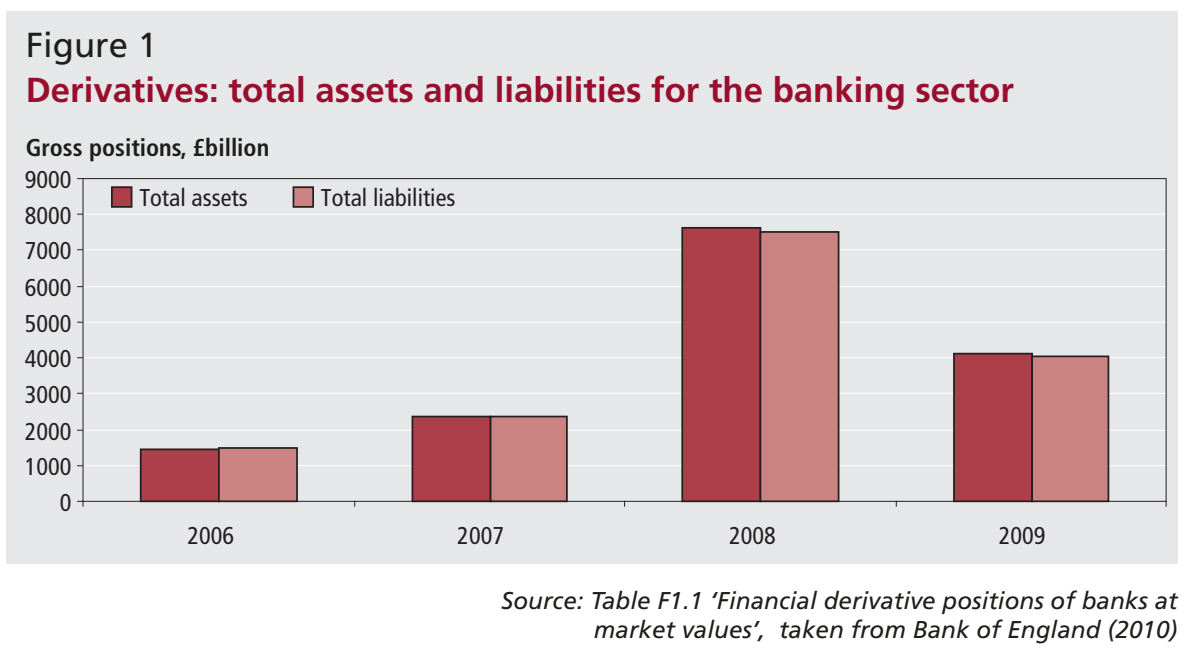

sheet of other sectors please see Table F1.1 of the Bank of England's publication Monetary and Financial Statistics (Bank of England 2010).

There was a sharp rise in banks' derivative positions in 2008, due to the financial turmoil. Frequent movements in interest rates, increased market activity together with a significant depreciation of sterling caused both interest rate products, as well as all contracts valued in foreign currency to rise sharply. These market movements have now stabilised and we are now seeing derivative positions fall towards pre-crisis levels by the end of 2009 .

\section{ANNEX}

\section{Model for deriving net transactions using balance sheet data, dealing profits and net spread earnings}

The following explanation outlines the rationale behind approximating net transactions as change in value of derivatives portfolio less 'dealing profits less net spread earnings'.

Book-keeping identities for DQ and PL forms

$\checkmark \quad$ value of a derivatives portfolio, at end of period

A acquisitions during period

D disposals during period

HGL net holding gains and losses during period

$X \quad$ net contractual payments received from portfolio during period

TDQ transactions, on DQ definition

IR definition of implied revaluations from DQ data

DP dealing profits less net spread earnings in period (form PL definition)

OCVA other changes in volume of assets

\section{Step 1}

Write the accounting identity for change in value of net asset position. Holding gains and losses $(\mathrm{HGL})$ are understood to be calculated after net payments or receipts of income. Making the assumption that 'other changes in volume of assets' (OCVA), such as write-offs, are typically zero in the case of financial derivatives, then:

$\Delta V_{t}=A_{t}-D_{t}+H G L_{t}+O C V A_{t}$

That is

$\Delta V_{t}=A_{t}-D_{t}+H G L_{t}$

In other words:

Change in value of derivatives portfolio $=$ Net transactions + Net holding gains/losses

\section{Step 2}

Form DQ definition of transactions. All income flows, $x$, are included as transaction terms. Negative sign on $x$ reflects that an income receipt is equivalent to a disinvestment of accrued income.

\section{CONTACT}

هelmr@ons.gov.uk

\section{REFERENCES}

Bank of England (2010) Monetary and Financial Statistics, available at www.bankofengland.co.uk/statistics/ms/ current/index.htm

ONS (2010) United Kingdom Economic Accounts, available at www.statistics.gov.uk/StatBase/Product. asp?vlnk=1904

The European System of Accounts (1995), available at

circa.europa.eu/irc/dsis/nfaccount/info/data/ esa95/en/een00244.htm

Semken, G (2005) 'Financial Derivatives in the UK Sector Balance Sheets and Financial Accounts', Economic Trends May 2005, available at

www.statistics.gov.uk/articles/economic trends/ET618Sem.pdf 
$T_{t}^{D Q}=A_{t}-D_{t}-x_{t}$

Step 3

Define a term 'implied revaluations' from the DQ changes in levels and transactions data. It follows that:

$\mathbb{R}_{t}=\Delta V_{t}-T_{t}^{D Q}=H G L_{t}+x_{t}$

\section{Step 4}

Dealing profits are defined on an International Accounting Standard (IAS) basis, subject to form PL statistical definitions. Write this definition as net holding gains and losses plus net income withdrawn:

$D P_{t}=H G L_{t}+x_{t}=I R_{t}$

\section{Step 5}

Therefore, in this framework, 'dealing profits and net spread earnings' and 'implied revaluations' are equivalent as each term is the sum of holding gains and losses plus net withdrawals of income. Other changes in volume are assumed to be zero. This should hold true both for an individual reporting bank, and for reporting banks in aggregate.

\section{Step 6}

Next, consider aggregate positions, indexing across reporting banks by letter (i). For each reporting bank (i), identify HGL and income (x) arising from non-bank counterparts (nb) and from other reporting bank counterparts (indexed by j not equal to i). Inter-bank HGL and income elements will offset each other on aggregation over the banking sector.

First, the position for bank (i):

$D P(i)_{t}=H G L(i, n b)_{t}+\sum_{j \neq i} H G L(i, j)_{t}+x(i, n b)_{t}+\sum_{j \neq i} x(i, j)_{t}$

Then, aggregate across banks (i), noting that the inter-bank positions offset.

$D P_{t}=\sum_{i} D P(i)_{t}=\sum_{i} H G L(i, n b)_{t}+\sum_{i} x(i, n b)_{t}$

Step 7

As

$\Delta V_{t}=A_{t}-D_{t}+H G L_{t}$

$A-D=\Delta V-H G L$

Where A-D represents net transactions over the period, and $\mathrm{HGL}$ can be approximated as dealing profits less net spread earnings, we can see net transactions can be estimated as change in value of derivatives portfolio less 'dealing profits less net spread earnings'. 